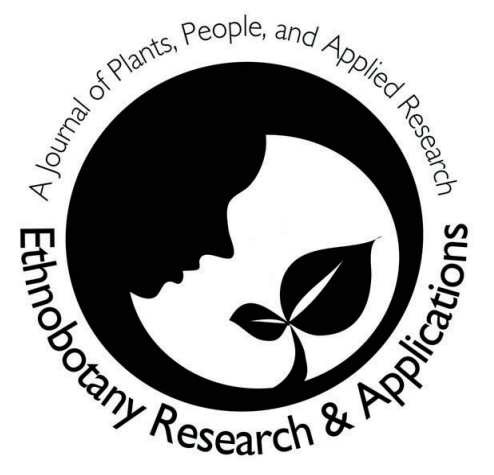

\title{
Past International Year of the Indigenous People? Into a new millennium.
}

\author{
Ramana Rao
}

The Gondwana has long since gone under

Flounders still, the gond

promised lands in plunder

Romany gypsy is chased by a hound

haunted by memories fond

Beyond the blue yonder

the banjara has to wander

Extinct the Moa, the Maori, reel in a world eerie

the Sioux is pushed to the edge of Lake Erie

Samoa and Pitcairn

Somalia and Scottish cairn

Galloping Cossack

war painted Mohawk

Chenchu, Chenchita and Cherokee

along the swamps of Ofenofekee

Igloo, icefloe, the husky sledge

far the Eskimo on polar edge

In his seal and krill man has pollution to fill

Heaping indignity on the indigenous

amongst other crimes heinous

Alienating his land and custom picturesque

soulful to Deums on new world soil

Ere Conquistador's soulless despoil

The Bantu, the Toda

Arakan yama of Burmese pagoda

Theirs was the earth

Of skills, no dearth

But modernity has them so swamped they need urgently to be revamped

The sky above and the mud below

as people they weren't so low

When aboriginal from down under

comes up above, man would have corrected his blunder

\section{Correspondence}

Nature and indigenous people's nature, engender nurture greed in modern man's nature, endangers earth, now rupture

Ramana Rao, Wildlife Biology Section, Department of Zoology, Osmania University, Hyderabad, Andhra

Pradesh, INDIA. siriguri@hd2.dot.net.in

Ethnobotany Research \& Applications 2:73 (2004) 